\title{
Working Capital Management and Its Effect on Profitability (A Case study on Finchaa Sugar Factory)
}

\author{
Adugna Megenasa Biru \\ Lecturer, Wollega University, College of Business and Economics \\ Department of Accounting and Finance, P.O. Box: 395, Nekemte, Ethiopia
}

\begin{abstract}
The Working capital management plays an important role for success or failure of firms business because of its effect on firm's profitability as well as on liquidity. The aim of this study is to investigate the working capital management and its effect on profitability of Finchaa Sugar Factory (2007-2018). The study adopts explanatory research type. The necessary data required for this study was Secondary data. The secondary data was the audited financial statement of the firm for the period of 2007 to 2018. The researcher has studied the components of working capital and the effect of different variables including the day's inventory outstanding, day's sales outstanding, day's payables outstanding and Cash conversion cycle on the profitability of the company. Debt ratio, sales growth and Current ratio are used as control variable. The data was analyzed using correlation coefficients and multiple linear regression to study the relationship between variables. The result shows that Days inventory outstanding, day's receivables outstanding, day's payables outstanding, cash conversion cycle and sales growth are significantly affecting the profitability of the company. The Current ratio and debt ratio are insignificant in the research in affecting the profitability of the firm.
\end{abstract}

Keywords: Working Capital Management, profitability.

DOI: $10.7176 / \mathrm{EJBM} / 11-28-06$

Publication date:October $31^{\text {st }} 2019$

\subsection{INTRODUCTION}

The term working capital management refers to firms' investments in short-term assets-cash, marketable securities, account receivables and inventories. Moreover, working capital management is the same of liquidity management and it is related inversely with profitability theoretically. In other words, decision that tend to focus on the liquidity, it will tend to reduce the potential profitability of the company. (Hayajneh, 2011).

Working capital management is a very important component of corporate finance because it directly affects the liquidity and profitability of the company. It deals with current assets and current liabilities. Working capital management is important due to many reasons. For one thing, the current assets of a typical manufacturing firm accounts for over half of its total assets. For a distribution company, they account for even more. Excessive levels of current assets can easily result in a firm's realizing a substandard return on investment. However firms with too few current assets may incur shortages and difficulties in maintaining smooth operations (Horne and Wachowicz, 2000).

Efficient working capital management involves planning and controlling current assets and current liabilities in a manner that eliminates the risk of inability to meet maturing short term obligations on the one hand and avoid excessive investment in these assets on the other hand (Eljelly, 2004). Many surveys have indicated that managers spend considerable time on day-to-day problems that involve working capital decisions. One reason for this is that current assets are short-lived investments that are continually being converted into other asset types (Rao, 1989). With regard to current liabilities, the firm is responsible for paying these obligations on a timely basis. Liquidity for the ongoing firm is not reliant on the liquidation value of its assets, but rather on the operating cash flows generated by those assets (Soenen, 1993). Taken together, decisions on the level of different working capital components become frequent, repetitive, and time consuming.

Researchers have approached working capital management in numerous ways.. According to Deloof, (2003), the way that working capital is managed has a significant impact on profitability of firms. Such results indicate that there is a certain level of working capital requirement, which potentially maximizes returns.

For many manufacturing firms, the current assets account for over half of their total assets Deloof, (2003). The management of working capital may have both negative and positive impact on firm's profitability, which in turn, has negative and positive impact on the shareholders' wealth. This study seeks to explore in detail these effects.

\subsection{Statement of the problem}

In every private and public enterprise, the management of working capital is crucial. As working capital maintains the details necessary to conduct the day to day activities, failure in proper working capital management may result in disruption of operation, and ultimately bankruptcy. The effective management of each component of working capital is essential for the enterprise to sustain its regular operation, and to maintain satisfactory level of liquidity 
and to maximize its profit. The problem is that enhancing profits at the cost of liquidity can bring serious problems to the firm. If we do not care about profit, we cannot survive for a longer period. On the other hand, if we do not care about liquidity, we may face the problem of insolvency or bankruptcy (Rehamen and Nasr, 2007). On the basis of this, this study has an important role in providing information about the quality of management and later on can help to control cost of holding current asset and to control cost of financing. Moreover, it ensures adequate level of realizable cash and avoids the losses caused by inadequate working capital. It can also help to control insolvency. This situation makes the study relevant. For these reasons working capital management should be given proper consideration and will ultimately affect the profitability of the firm. It is also one of the factors that ensure the survival of the firm.

The Ethiopian Government is extensively expanding sugar development projects so as to: Narrow the gap between demand and supply of sugar; Improve life style of citizens by creating vast job opportunities and Earn foreign currency by exporting the product. Sugar development sector is one among other huge projects which enables industry take a leading role in the nation's economy. Ethiopia has huge human as well as natural resources which enable the nation to broaden this export oriented manufacturing industry sector and its productivity. Ethiopian government planned to produce 520 thousand tons of sugar in 2019 (www.ethiopiansugar.com).

The achievement of this plan in the sugar industry depends upon the liquidity, productivity and profitability of the business enterprise. The liquidity can be achieved by effectively managing different parts of working capital such as inventory management, receivable management, account payable management, cash management and proper debt collection policy. Profitability can also be increased if working capital is effectively managed. This study was made to evaluate the working capital management and its impact on profitability in the case of Finchaa Sugar Factory.

\subsection{General objective}

The general objectives of the study was to assess working capital management and its effects on profitability of Finchaa Sugar Factory.

\subsubsection{Specific objectives}

The specific objectives for undertaking this study are listed as below.

$>$ To investigate the existing working capital elements, i.e. the level and compositions of current assets and current liabilities for successive 12 years (2007-2018 G.C).

$>$ To examine the impact of working capital management metrics such as days inventory outstanding, accounts receivables days, accounts payable days and cash conversion cycle on profitability

$>$ To establish a relationship between working capital Management and profitability over a period of twelve years.

$>$ To make suggestions and recommendations so as to improve the company's working capital management

\subsection{Scope and limitations of the study}

The study recognized its scope as well as the limitation. The topic under study is very vast in its nature. Due to this, this research project is restricted to the different practice around working capital management, components of working capital and on few different metrics to find out how a company can perform better by managing working capital. Although it is important to study the working capital management and its effect on profitability of all sugar industries in Ethiopia, it is difficult to conduct the study of all because of the topic under question needs much time and money to conduct an elaborate study of all the Sugar Factory and come to conclusion for Ethiopia as a whole. Due to these constraints, this study has mainly focused on the impact of working capital management on profitability of Finchaa Sugar which is found in Horo Guduru Wollega Zone of Oromiya Region in Abay Chommen District at Finchaa Valley Agamsa area, 350 Kilo Meters from North West of Addis Ababa. The result of this research, therefore, is limited to Finchaa Sugar Factory in particular and could not be generalized to all Sugar industry of Ethiopia.

\section{A REVIEW OF THE EMPIRICAL FINDINGS}

Empirical evidence on the relationship between WCM practices and financial performance indicates that these practices have a significant impact on both profitability and liquidity. Additionally, the findings seem to align with documented literature with a few exceptions. Variations occur due to the different methodologies used, the sample sizes or variables applied, and the different environments within which firms operate.

In intention to discover the relationship between efficient working capital management and firm's profitability, Shin and Soenen (1998) used net-trade cycle (NTC) as a measure of working capital management. NTC is basically equal to the CCC whereby all three components are expressed as a percentage of sales. The reason by using NTC because it can be an easy device to estimate for additional financing needs with regard to working capital expressed as a function of the projected sales growth. This relationship is examined using correlation and regression analysis, by industry and working capital intensity. Using a composted sample of 58,985 
firm years covering the period 1975-1994, in all cases, they found, a strong negative relation between the length of the firm's net-trade cycle and its profitability. In addition, shorter NTC are associated with higher risk-adjusted stock returns. In other words, Shin and Soenen (1998) suggest that one possible way the firm to create shareholder value is by reducing firm's NTC.

The study of Shin and Soenen (1998) was consistent with later study on the same objective that done by Deloof (2003) by using sample of 1009 large Belgian non-financial firms for the period of 1992-1996. However, Deloof (2003) used trade credit policy and inventory policy are measured by number of days accounts receivable, accounts payable and inventories, and the cash conversion cycle as a comprehensive measure of working capital management. He founds a significant negative relation between gross operating income and the number of day's accounts receivable, inventories and accounts payable. Thus, he suggests that managers can create value for their shareholders by reducing the number of day's accounts receivable and inventories to a reasonable minimum. He also suggests that less profitable firms wait longer to pay their bills.

Recent study by Raheman and Nasr (2007) is to examine working capital management effect on liquidity as well on profitability of the firm. In this study, they use sample of 94 Pakistani firms listed on Karachi Stock Exchange for a period of 6 years from 1999-2004. Similar to Shin and Soenen (1998), Deloof (2003), results of this study show that a strong negative relationship between components of the working capital management and profitability of the firm

In other study, Lyroudi and Lazaridis (2000) used food industry in Greek to examined the cash conversion cycle (CCC) as a liquidity indicator of the firms and attempts to determine its relationship with the current and the quick ratios, with its component variables, and investigates the implications of the CCC in terms of profitability, indebtness and firm size. The results of their study indicate that there is a significant positive relationship between the cash conversion cycle and the traditional liquidity measures of current and quick ratios. The cash conversion cycle also positively related to the return on assets and the net profit margin but had no linear relationship with the leverage ratios. Conversely, the current and quick ratios had negative relationship with the debt to equity ratio, and a positive one with the times interest earned ratio. Finally, there is no difference between the liquidity ratios of large and small firms.

Samiloglu \& Damirgunes (2008) said that even though the profitability is constantly positive, inaccurate working capital management procedures may lead to bankruptcy of the firm. They suggest that current, acid test, and cash ratios as traditional measures of liquidity are incompetent and static balance sheet measures that cannot provide detailed and accurate information about working capital management effectiveness. In their research formulas used for calculating them consider both liquid and operating assets in common and traditional ratios are not meaningful in terms of cash flow.

Nandi (2011) made an attempt to examine the influence of working capital management on corporate profitability. For assessing impact of working capital management on profitability of National Thermal Power Corporation Ltd. during the period of 10 years i.e., from 1999-2000 to 2008-09 Pearson "s coefficient of correlation and multiple regression analysis between some ratios relating to working capital management and the impact measure relating to profitability ratio (ROI) had been computed and applied. An attempt had been undertaken for measuring the sensitivity of return of investment (ROI) to changes in the level of working capital leverage (WCL) of the studying company.

Karaduman, Akbas \& Caliskan (2011) have tried to shed light on the empirical relationship between efficiency of working capital management and corporate profitability of selected companies in the Istanbul Stock Exchange for the period of 2005-2009. The companies should focus on working capital management in order to increase their profitability by seriously and professionally considering the issues on their cash conversion cycle which was derived from the number of day's accounts payable, the number of day's accounts receivable and the number of days of inventories. The findings suggested that it may be possible to increase profitability by improving efficiency of working capital.

Mallick And Sur (1998) made an attempt to analyze the impact of working capital management on profitability in Indian Tea industry with the help of some statistical tools and techniques. The study revealed that, out of the nine ratios relating to working capital management five ratios registered positive association and the remaining four ratios showed negative correlation with the profitability indicator. Rao \& Rao (1999) undertook a similar type of study where ten ratios relating to working capital management were selected. Out of these indicators, positive association was noticed only in three.

Cheakraborty (2008) evaluated the relationship between working capital and profitability of 25 selected companies in the Indian pharmaceutical industry during the period 1996-97 to 2007-08. Inadequacy of working capital may lead to the firm to insolvency, whereas excessive working capital implies idle funds which earns no profits. Therefore, efficient management of working capital is an integral part of the overall corporate strategy to improve corporate profitability. The partial regression coefficients shown in the multiple regression equation of ROCE on CR, ITR and DTR fitted in this study revealed that the liquidity management, inventory management and credit management made positive contribution towards improvement of the corporate profitability. 
Though researchers have studied the relationship between the components of working capital management and the corporate profitability with reference to different sectors no studies have been conducted on the effect of working capital management on profitability with reference to sugar industry in Ethiopia. This reason has been a motivational force to do a research on the sugar sector. For this purpose, secondary data of the industry has been taken during 2007-2018.

\subsection{Conceptual Framework}

The following conceptual frame work is developed for the study.

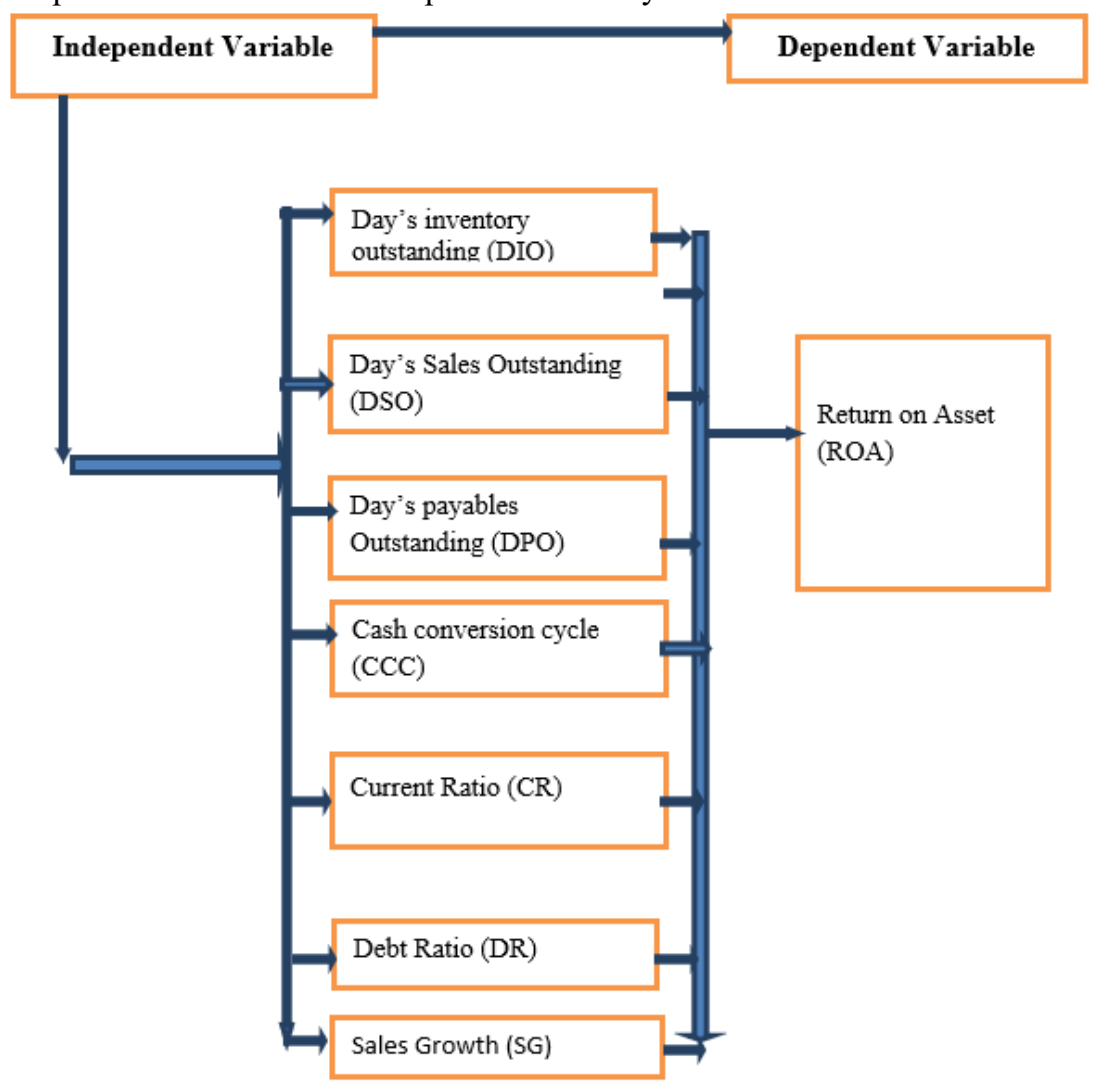

Source: Developed by Researcher, 2019

\section{Methodology}

The following are the methods and techniques adopted for collection of data and for their analysis in this study.

\subsection{Research Design and source of Data}

The study adopts explanatory research type. The purpose of explanatory research describes cause and effect relationship of dependent and independent variables. Here the researcher has tried to see the relationship existing between working capital management and its effects on profitability of the company. For this research secondary data were used as a source of data. The financial statements for the past twelve years (2007-2018), such as income statements and balance sheets of the company were used as the main source of data.

\subsection{Method of Data Collection}

The secondary data was gathered from Finchaa Sugar Factory. The variables used in the study, dependent, independent and control variables, all are calculated and drawn from the financial statements of the company.

\subsection{Method of Data Analysis}

Once data were found acceptable, STATA 13.0 software program was used for data process. The Data was analyzed using descriptive statistical techniques and presented by the use of charts, tables and graphs. The statistical Correlation analysis is made to determine the relationship between an efficient management of working capital and corporate profitability for the period under study. The Quantitative analysis also includes Multiple Regression analyses in order to shed more light on, and develop a better understanding of, the relationship of WCM and Profitability of the firm under study. 


\subsection{Description of Variable and Model Specification Description of Variable}

Most of the dependent and independent variables used in the study have been taken from the existing literature on working capital management. As stated before, Deloof (2003) has studied the relationship between working capital management and corporate profitability. He calculates the variable for the cash conversion cycle as (number of days accounts receivable + number of days inventory - number of days accounts payable). The measure for profitability is Return on Assets Along with working capital variables, the present study has taken into consideration some control variable such as the sales growth of the firm, the current ratio and its debt ratio.

\section{Dependent Variables}

a) Dependent variable:

The Return on Assets (ROA): It shows the profits earned per birr of assets and indicates how effectively the firm's assets are managed to generate revenues, although it might be biased due to off-balance-sheet activities (Habtamu, 2012). Average assets were used in this study, in order to capture any differences that occurred in assets during the fiscal year. ROA can be calculated as:

b) Independent variable:

$$
R O A=\frac{\text { Earning Before interest and Tax }}{\text { total assets }}
$$

\begin{tabular}{|c|c|c|}
\hline Variable & Calculation & Abbreviations \\
\hline $\begin{array}{ll}\text { Days } & \text { Inventory } \\
\text { Outstanding } & \end{array}$ & $=\frac{\text { Average Inventory }}{\text { cost of Goods Sold }} \boldsymbol{x}$ Number of days in year & $\mathrm{DIO}$ \\
\hline Days Sales Outstanding & $=\frac{\text { Average Account Receivable }}{\text { Average credit sales per day }}$ & $\mathrm{DSO}$ \\
\hline $\begin{array}{ll}\text { Days } & \text { Payable } \\
\text { Outstanding } & \end{array}$ & $=\frac{\text { Average value of creditors }}{\text { cost of Goods Sold }} \boldsymbol{x}$ Number of days in year & DPO \\
\hline Cash Conversion Cycle & $=\mathrm{DIO}+\mathrm{DSO}-\mathrm{DPO}$ & $\mathrm{CCC}$ \\
\hline Current Ratio & $=\frac{\text { Current Asset }}{\text { Current Liabilities }}$ & $\mathrm{CR}$ \\
\hline Debt Ratio & $=\frac{\text { Total liabilities }}{\text { Total asset }}$ & DR \\
\hline Sales Growth & $=\frac{T \text { his Year's sales }- \text { Previous year'ssales }}{\text { previous year'ssales }}$ & $\mathrm{SG}$ \\
\hline
\end{tabular}

\section{Specification of models}

Multiple regression analysis was used to investigate the effect of working capital management metrics (Days inventory Outstanding (DIO), Days sales Outstanding (DSO), Days Payable Outstanding (DPO), The Cash Conversion Cycle (CCC), Current ratio (CR) Debt ratio (DR) and Sales Growth (SG) on Net Operating Profitability (NOP).

\section{Regression functions}

The equation of multiple regressions on this study is generally built around two sets of variables, namely dependent variables (profitability) and independent variables (Days inventory Outstanding, Days sales Outstanding, Days Payable Outstanding and The Cash Conversion Cycle).

$$
\begin{aligned}
& \text { ROA }=\beta 0+\beta 1(\text { DIO t })+\beta 2(\text { DSO t })+\beta 3(\text { DPO t })+\beta 4(\text { CCC t })+\beta 5(\text { CR t })+\beta 6(D R ~ t)+\beta 7(\text { SG t })+\varepsilon \\
& \text { Where: }
\end{aligned}
$$

ROA: Return on Asset, in time $\mathrm{t}$

DIO: Days inventory Outstanding, in time $t$

DSO: Days sales Outstanding, in time $t$

DPO: Days Payable Outstanding, in time t

CCC: Cash Conversion Cycle, in time $\mathrm{t}$

CR: Current Ratio, in time $\mathrm{t}$

DR: Debt Ratio, in time t

SG: Sales Growth, in time t

$\beta 0$ : Intercept of the equation

$\beta$ : coefficients of the independent variables

$\varepsilon$ : The error term. 


\section{DATA PRESENTATION, ANALYSIS AND DISCUSSION}

\subsection{Trend of working capital}

Trend analysis helps financial managers and analysts to see whether the current working capital situation is improving or deteriorating.

Working capital trend

\begin{tabular}{|l|c|c|c|}
\hline Year & Current asset & Current liabilities & Net working capital \\
\hline 2007 & $584,473,498.96$ & $422,149,633.81$ & $162,323,865.15$ \\
\hline 2008 & $798,068,123.73$ & $454,640,545.89$ & $343,427,577.84$ \\
\hline 2009 & $1,055,967,488.48$ & $543,663,395.84$ & $512,304,092.64$ \\
\hline 2010 & $1,492,460,486.19$ & $736,742,799.28$ & $755,717,686.91$ \\
\hline 2011 & $2,051,404,501.46$ & $962,053,203.21$ & $1,089,351,298.25$ \\
\hline 2012 & $1,677,116,341.28$ & $483,540,087.49$ & $1,193,576,253.79$ \\
\hline 2013 & $1,870,939,245.17$ & $653,278,641.69$ & $1,217,660,603.48$ \\
\hline 2014 & $1,615,916,284.95$ & $572,447,533.30$ & $1,043,468,751.65$ \\
\hline 2015 & $1,710,152,950.08$ & $956,479,685.86$ & $753,673,264.22$ \\
\hline 2016 & $1,758,535,884.24$ & $1,526,789,100.37$ & $231,746,783.87$ \\
\hline 2017 & $1,844,600,548.72$ & $1,626,818,768.25$ & $217,781,780.47$ \\
\hline 2018 & $2,100,066,138.53$ & $1,889,600,994.82$ & $210,465,143.71$ \\
\hline
\end{tabular}

Source: from financial statement of the company

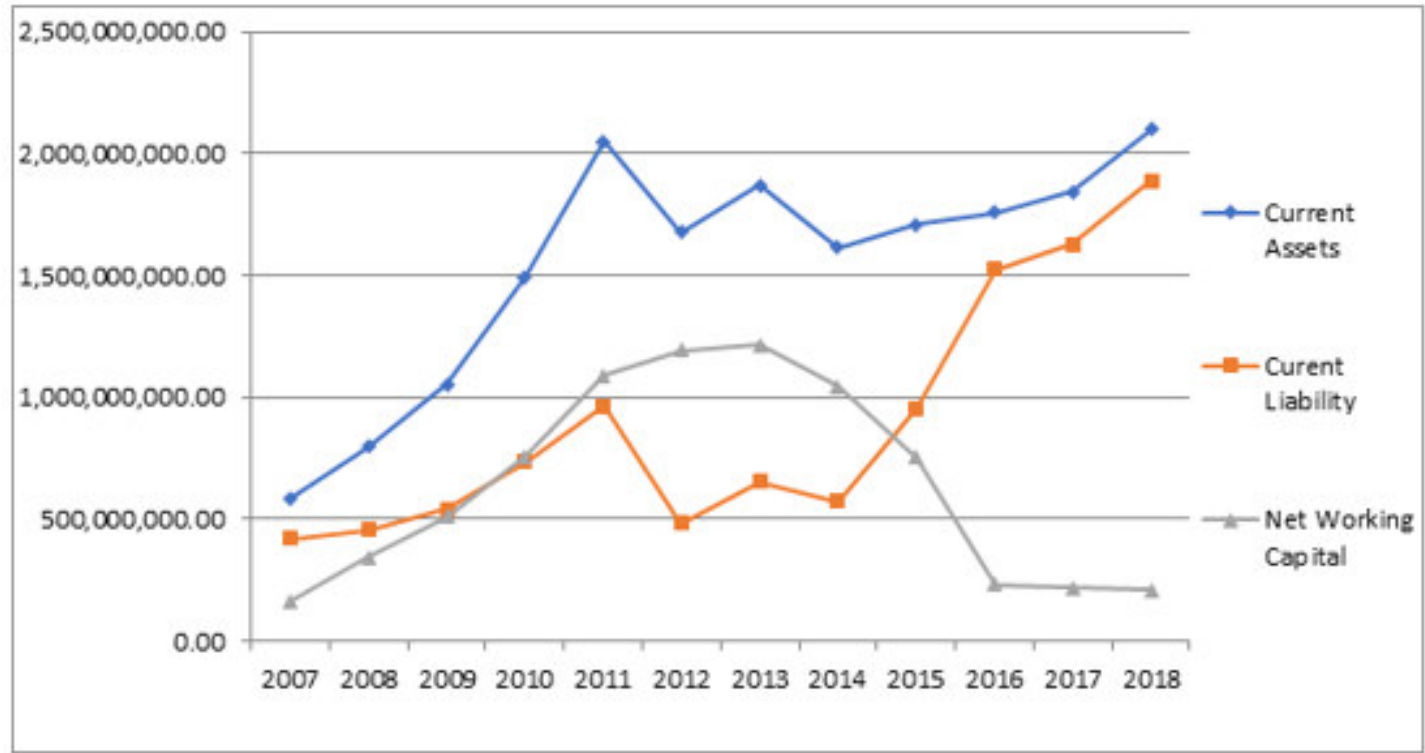

It is evident from table 4.3 that the size of current asset of the company shows a significant increase from year 2007 to 2011. But after year 2011 to year 2014 it shows a fluctuating trend and the shows a minor increase until year 2018 as compared to the rate by which current liabilities was increased. As it can be observed from the table above the current liabilities shows increasing trend from the year 2007 to year 2011. In year 2012 it was decreased by the highest rate. But from year 2014 to 2018 it was increased by the highest rate. Analyzing working capital direction of change over a period of time is of a crucial importance. The working capital trend of Finchaa Sugar Factory is presented in table 4.3. It is evident from the table that the working capital of the factory shows an increasing trend from year 2007 to 2013 . From year 2014 to 2018 it shows the decreasing trend. The reason of increase in net working capital from year 2007 to 2013 is because of the rate at which the current assets increased are greater than the rate at which the current liabilities increased. In year 2014 to 2018 the net working capital balance was decreased because of substantial increase in the current liabilities and slight increase in the current assets. It can be concluded from the above fact the net working capital holding was improved in year 2007 to year 2013 because of the fact that the current assets of the company increased at a faster rate relative to increase in the current liabilities. But in year 2014 to year 2018 net working capital holding was highly deteriorated because the faster increase in the current liabilities.

\subsection{Analysis of Impact of working capital metrics on profitability}

Working capital cycle indicates the length of time between a companies' paying for materials, entering into stock and receiving the cash from sales of finished goods. It can be determined by adding the number of days required 
for each stage in the cycle. (The institute of chartered accountants of India).

The main metrics working capital and its effective management are days inventory outstanding (DIO), days sales outstanding (DSO), days payables outstanding (DPO), cash conversion cycle (CCC).

\subsubsection{Correlation Analysis}

Correlation analysis was used to see the relationship between variables such as those between working capital management metrics and profitability. For pairs of variables the correlation, which is a measure of the degree of linear relationship, is shown. A disadvantage of the Correlation Matrix is that although it shows linear relations between variables is does not show which variable influences the other (Deloof 2003). For quantitative analysis correlation is used to measure the degree of association between different variables under consideration. Pearson correlations are calculated for all variables used in the study starting with the Pearson's correlation results. If efficient working capital management increases profitability, one should expect a negative relationship between the measures of working capital management and profitability variable.

This paper finds negative correlations between the number of day's inventory, day's accounts payable and days accounts receivable with profitability. The following table 4.5 presents the correlation coefficient summery result as shown below.

Correlation result

\begin{tabular}{r|rrrrrrrr} 
& roa & dio & $d s 0$ & dpo & ccc & cr & sg & $d r$ \\
\hline roa & 1.0000 & & & & & & & \\
dio & -0.8200 & 1.0000 & & & & & & \\
dso & -0.9692 & 0.7973 & 1.0000 & & & & & \\
dpo & -0.6314 & 0.5643 & 0.6616 & 1.0000 & & & & \\
ccc & -0.6728 & 0.8343 & 0.7472 & 0.6704 & 1.0000 & & \\
cr & -0.4670 & 0.5162 & 0.4554 & 0.4374 & 0.4994 & 1.0000 & & \\
sg & 0.8418 & -0.6248 & -0.7969 & -0.3360 & -0.5819 & -0.3064 & 1.0000 & \\
$d r$ & 0.2643 & -0.2562 & -0.3262 & -0.3388 & -0.1285 & -0.4336 & -0.0624 & 1.0000
\end{tabular}

Source: STATA 13.0 Results, 2019

In Table 4.5 is shown the Correlation Matrix for the variables included in this study. The result of correlation analysis shows a negative coefficient -0.8200 , between days inventory outstanding and return on asset. That means if days inventory outstanding increase the net profitability will decrease. It will negatively impact the profit. The Correlation results between days sales outstanding and the return on asset also indicate the negative relationship. The correlation coefficient is -0.9692 . It also indicates that if the firm waits more time in collecting receivables, it will negatively affect its profitability. The correlation results between days payables outstanding and net return on asset also indicate the negative relationship. The coefficient is -0.6314 It means that since the company is at loss or less profitable it waits longer period to pay their bills. Speeding up payments to suppliers might increase profitability because firms often receive a substantial discount for prompt payment. The cash conversion cycle which is a comprehensive measure of working capital management also has a negative coefficient with -.6728. It means that if company's cash conversion cycle is increased it will have negative effect on the profitability of the company. By analyzing the results, the researcher concludes that if the firm is able to reduce these time periods, then the firm is efficient in managing working capital. This efficiency will lead to increasing its profitability. Current ratio is a traditional measure of checking liquidity of the firm. In this analysis the current ratio has a negative relationship with return on asset or profitability. The coefficient is -0.4670 It indicates that the larger the applied resources in current assets, the lower the profitability and a lower level of Net working capital by the same time that it increases the profitability of the firm, by reducing the long-term funds that could be transferred to less profitable assets. According to Assaf Neto (2003, p.22), the greater the amount of funds invested in current assets, the lower the profitability, and by the same time the less risky is the working capital strategy. The correlation result between sales growth and return on asset shows a positive relationship with coefficient of 0.8418. This indicates that growth in sales positively affect the profitability of firm. Debt ratio also shows positive relationship with the dependent variable, which means that, when leverage of the firm increases, it will positively affect its profitability.

correlation also displays a significant positive relationship between days inventory outstanding and cash conversion cycle, and days sales outstanding and cash conversion cycle which means that if a firm takes more time to sell inventory and collect cash against the credit sales it will increase its operating or cash conversion cycle, which will ultimately affect the profit. 
The average payment period and cash conversion cycle have a positive relationship. This means that if the company takes longer time to pay their payables then the cash conversion period will increase. Now, these negative relationships between Cash conversion cycle, Average collection period, Average payment period and Inventory turnover in days with the profitability of companies are consistent with the literature review and have an effect on the profitability of company.

\subsubsection{Model Diagnostic Test}

\section{i) Variance inflation factor (VIF) test}

Variance inflation factor (VIF) is a measure of the amount of multicollinearity in the set of multiple regression variables. The VIF value used to diagnose whether there exists any multicollinearity problem. If the result of VIF shows that all independent variables values are less than 10 diagnostic indicates that a multicollinearity assumption is not violated. Since table 4.6 below shows mean value of variance inflation factor (VIF) of all independent variable is 4.34 or less than 10 the multicollinearity assumption is not violated.

\begin{tabular}{r|rr} 
Variable & VIF & 1/VIF \\
\hline dso & 9.49 & 0.105397 \\
sg & 5.00 & 0.200052 \\
cCC & 4.74 & 0.210985 \\
dio & 4.60 & 0.217208 \\
dpo & 2.66 & 0.376433 \\
dr & 2.17 & 0.460197 \\
Cr & 1.74 & 0.575765 \\
\hline Mean VIF & 4.34 &
\end{tabular}

Source: STATA 13.0 Results, 2019

\section{ii) Heteroscedasticity test: white test}

According to Brooks (2008), Heteroskedasticity means that error terms do not have a constant variance. If Heteroskedasticity occur, the estimators of the ordinary least square method are inefficient and hypothesis testing is no longer reliable or valid as it was underestimating the variances and standard errors. There are several tests to detect the Heteroskedasticity problem, which are Park Test, Glesjer Test, and other test. However, In this study, Breusch-Pagan / Cook-

Weisberg test for Heteroskedasticity was employed. Since, table 4.6 below, shows that the test result for ROA regression analysis's p-values are considerably in excess of 0.05 , we can say that there is no evidence for the presence of heteroscedasticity.

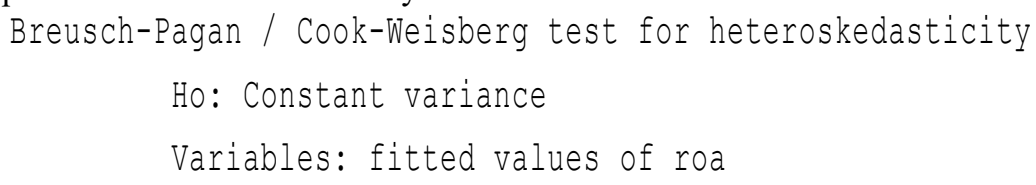

$$
\begin{array}{ll}
\operatorname{chi2}(1) & =0.09 \\
\text { Prob }>\operatorname{chi2} & =0.7610
\end{array}
$$

Source: STATA 13.0 Results, 2019

\section{iii) Autocorrelation test: Durbin-Watson (DW) test}

According to Chris brooks $(2008 ; 240)$, the disturbance terms is the covariance between the error terms over time (or cross- sectionally, for that type of data) is zero. In other words, it is assumed that the errors are uncorrelated with one another. In addition, he said that if the errors are not uncorrelated with one another, it would be stated that they are ,auto correlated ${ }^{\text {ee }}$ or that they are ,serially correlated ${ }^{\text {ee }}$. To test this assumption the Durbin-Watson (DW) statistical test was applied. As table 4.8 below indicates that the DW test result is 1.74022 for the profitability measure; return on asset. This indicates that there was no serious evidence of autocorrelation in the data since the DW test result is not far from two.

\begin{tabular}{|l|l|}
\hline Test & ROA \\
\hline Durbin-Watson test & 1.74022 \\
\hline
\end{tabular}

Source: STATA 13.0 Results, 2019 


\subsubsection{Regression analysis between return on asset and explanatory variables}

Multiple linear regression techniques have been applied in order to study the joint influence of the selected ratios relating to working capital management of the profitability of the company. In this study, DIO, DSO, DPO, CCC, $\mathrm{CR}, \mathrm{SG}$ and DR have been taken as the explanatory variable and ROA has been used as the dependent variable. DIO, DSO, DPO, CCC are converted to the natural logarithms

\begin{tabular}{|c|c|c|c|c|c|}
\hline Source & SS & $d f$ & MS & Number of obs & 12 \\
\hline & & & & $E(7$, & 150.50 \\
\hline Model & .003672045 & 7 & .000524578 & Prob $>F$ & 0.0001 \\
\hline Residual & .000013942 & 4 & $3.4855 e-06$ & R-squared & 0.9962 \\
\hline & & & & Adj R-squared & 0.989 \\
\hline Total & .003685987 & 11 & .00033509 & Root MSE & .00187 \\
\hline
\end{tabular}

\begin{tabular}{r|rrrrrr}
\hline roa & Coef. & Std. Err. & $t$ & P $>$ t $\mid$ & [95\% Conf. Interval] \\
\hline dio & -.019787 & .0035932 & -5.51 & 0.005 & -.0297634 & -.0098106 \\
dso & -.0593367 & .0079802 & -7.44 & 0.002 & -.0814934 & -.03718 \\
dpo & -.0130844 & .0040358 & -3.24 & 0.032 & -.0242895 & -.0018793 \\
ccc & .0341529 & .0055663 & 6.14 & 0.004 & .0186985 & .0496074 \\
cr & -.001184 & .0008238 & -1.44 & 0.224 & -.0034711 & .0011032 \\
sg & .0129963 & .0041455 & 3.14 & 0.035 & .0014865 & .024506 \\
dr & -.0090265 & .0056381 & -1.60 & 0.185 & -.0246803 & .0066274 \\
cons & .1347439 & .0168346 & 8.00 & 0.001 & .0880036 & .1814841 \\
\hline
\end{tabular}

Source: STATA 13.0 Results, 2019

According to the final results above by applying time series data to study working capital management on profitability for the period 2007 to 2018 . As it can be seen from the above regression result there are 12 number of observations which means the data from 2007-2018 was used for this analysis. The F statistics value of 150.50 indicates that the independent variables are jointly significant in predicting the dependent variable with Prop $>\mathrm{F}$ of 0.0001 which indicates a good fitness of the predictability of the model used. The R squared value of 0.9962 shows a variation in dependent variable that is explained by independent variables. Since the $\mathrm{R}$ square is high the better the model and the more the predictive power the variables have. The Coefficient indicates the estimates for intercept and slope. The sign of coefficient shows the direction of the relationships between the dependent and the independent variables. From the result the summery shows Days inventory outstanding, Days sales outstanding, days payables outstanding have a Negative significant impact on Return on Asset (ROA) or profitability of the firm. Whereas, sales growth and cash conversion cycle have a positive significant impact on profitability. However, the cash positive impact of cash conversion cycle is not in line with the existing literatus.

Based on the magnitude of weighted beta, it can be concluded that if all independent variables are ignored, then the firm itself have the value of 0.134 on return on asset. However, if there is one additional standard deviation changes in independent variables; Days inventory outstanding, Days sales outstanding, days payables outstanding and sales growth would increase or decrease the firms return on asset with a value of $-0.019,-0.059,-0.013$, and 0.012 respectively.

This indicates that, 1 day increase in day's inventory outstanding would lead to reduce return on asset by about $0.019 \%$. 1 day increase in days sales outstanding would lead to decrease return on asset by more than $0.059 \%$, 1 day's payables outstanding would lead to decrease return on asset by more than $0.013 \%, 1 \%$ increase in sales would lead to increase return on asset by more than $0.012 \%$.

\section{CONCLUSIONS \& RECOMMENDATIONS}

\subsection{Conclusion}

For many firms working capital investments make out a large part of their short-term assets. This study is undertaken with the intention of analyzing working capital management and its effect on profitability of Finchaa Sugar Factory. An improved management of this working capital can be expected to have an important influence on the corporate profitability of firms. This section of the study summarizes the major findings of the study as follows.

> Working Capital Management has impact on profitability of the company and plays a key role in value creation for shareholders as longer the days inventory outstanding, the days sales outstanding and days payable 
outstanding has negative impact on Return on assets of the company.

$>$ The day's inventory outstanding, days sales outstanding and days payable outstanding are taken as a comprehensive components of working capital management. These variables have negative significant impact on Return on Asset or profitability of the firm. Deloof (2003) concluded the same result for the study of Belgian firms. Therefore, be profitable, firms must try to keep these numbers of days to minimum level. By using these variables, the efficiency of working capital management can easily be improved.

$>$ The cash conversion cycle which is a comprehensive measure of working capital management also has a negative relationship with profitability but it has statistically positive significant impact on return on asset. This result is not inline the existing literature.

$>$ Sales growth (SG) has proved statistically significant and has impact on Return on Assets (ROA) or profitability of the firm. This indicates that growth in sales positively affect the profitability of firm. Same result was concluded by Deloof (2003), Shin and Soenen (1998), Rajan and Zingales (1995) and Myers and Majlof (1984) but in this case gearing ratio is insignificant.

$>$ Debt Ratio have statistically insignificant impact on Return on Assets in this research but it has a positive relationship with Return on Asset which shows that higher will be the leverage higher will be the profitability of the firm.

$>$ Current ratio is statistically insignificant impact on profitability of the firm. But in this analysis the current ratio has a negative relationship with return on asset or profitability. The negative coefficient indicates that the larger the applied resources in current assets, the lower the profitability and a lower level of Net working capital by the same time that it increases the profitability of the firm, by reducing the long-term funds that could be transferred to less profitable assets.

\subsection{Recommendation}

On basis of the above analysis researcher suggest that these results can be further strengthened if the company manages their working capital in more efficient ways. Management of working capital means "management of current assets and current liabilities, and financing these current assets".

$>$ If the company properly manages their cash, accounts receivables and inventories in a proper way, this will ultimately increase profitability of the company. Thus, the firms can manage their working capital through reduce the length time between sell the goods and receive cash of sales, it can do that by accelerating its collections. And it also reduces the length time between convert the raw materials into finished goods to sell these goods through.

$>$ On the other hand, the firms should shorten the length time between purchase goods to pay their purchases. They should make such collection and payment policies which are in favor of the firm and existing policies should be thoroughly reviewed. The firm should decrease their payment and receivable cycle. This can only be done when there will be professional management. The results suggest that the factory should keep optimum level of inventory and cash conversion. All these will lead to shorten the cash conversion cycle and then lead to achieve the optimal profitability.

\subsection{Direction for Further Research}

Every sugar manufacturing sector and other different sectors in Ethiopia should be analyzed for efficient working capital management so it can be understood that which factors affects the working capital management more and how working capital management can increase profitability. The scope of further research may be extended to the working capital components management including cash, marketable securities, receivables and inventory management

\section{Reverences}

Assaf Neto, A. (2003). Finanças Corporativas e Valor. São Paulo: Atlas.

Banomyong, R. (2005). Measuring the cash conversion cycle in an international supply chain. Annual Logistics Research Network, ( pp.7-9).plymouth.

Block, Y., \& Hirt, G. (1987). Financial Management Theory. New Delhi: The MacVllian Press Ltd.

Brealey A. Richard, Myers C. Stewart, and Marcus J. Alan, 2004, Fundamentals of Corporate Finance, McRAWHILL, INC

Debasis, Sur. (1997). Working capital management in Colgate Palmolive (India) Ltd. -A case study. The Management Accountant.

Deloof, M and Jegers, M. 1996. "Trade credit, product Quality, and Intra Group Trade:Some European Evidence", Financial Management, Vol 25 No 3 pp. 33-43

Deloof, M. (2003). Does working capital management affect profitability of Belgian firms? Journal of Business Finance \&Accounting, 30(3\&4), 573-587.

Dimitrios P. Koumanakos 2008, The effect of inventory management on firm performance, International Journal 
of Productivity and Performance Management, Vol. 57 No.5, pp.355-369

Eljelly, A. (2004). Liquidity-profitability tradeoff: An empirical investigation in an emerging market. International Journal of Commerce \& Management, 14(2), 48-61.

Firth, Michael. (1976). Management of working capital. New York: The MacMllian Press Ltd.

Gentry, James A.; Vaidyanathan, R.; Hei Wai Lee. (1990). A weighted cash conversion cycle, The Journal of the Financial Management Association, Spring, Vol.19 Issue 1, pp. 90

Habtamu, N. (2012). Determinants of Bank Profitability: An Empirical Study on Ethiopian Private Commercial Banks. Addis Ababa University

I. M. Pandey. (2000). Financial Management theory and practices. New Delhi: Vikas publishing company.

Jarvis, R., Kitching, J., Curran, J. and Lightfoot, G. (1996). The Financial Management of Small Firms:An Alternative Perspective. ACCA Research Report No. 49

Kargar, J. and Blumenthal, R. A. (1994). Leverage Impact of Working Capital in Small Businesses. TMA Journal, $14(6), 46-53$.

Keown J. Arthur, Martin.D. John, Petty J.William, Scott F.David, Foundations of Finance: The logic and practice of financial management, Pearson Prentice Hall 2006

Khan,L., \& Jain, D. (1997). Financial Management. New Delhi: Tata McGrew Hill publishing company.

Lazaridis, I. \& Tryfonidis, D. (2006). Relationship between working capital management and profitability of listed companies in the Athens stock exchange. Journal of Financial Management and Analysis, 19(1), 26-35.

Lyroudi, K. \& Lazaridis, Y. (2000). The cash conversion cycle and liquidity analysis of the food industry in Greece (Electronic Version). EFMA 2000 Athens. (Online source). Retrived from http://ssrn.com/paper=236175.

Mathur B. Satish 2003, Working Capital Management and Control Principles \& Practice, New Delhi

Mehta, D. R. (1974). Working capital Management, Englewood Eliffs, New Jersey, and Prentice Hall of India Pvt. Ltd.

Michalski Grzegorz, 2008, Determinants of Accounts Receivable Level: Portfolio Approach in Firmes Trade Credit Policy, Working paper

M Y Khan. \& P K Jain. Financial management Text, proplems and cases. New Delhi

Nandi, K. C (2011), "Impact of Working Capital Management on Profitability, A Case Study of National Thermal Power Corporation Ltd.”, The Management Accountant, January 2011, pp.22-27

Niskanen, J. and M. Niskanen, 2006, The determinants of Corporate Trade Credit Policies in a Bank-dominated Financial Environment: the Case of Finnish Small Firms

Osama Suhail Hayajneh. (2011). The Impact of Working Capital Efficiency on Profitability - an Empirical Analysis on Jordanian Manufacturing Firms. 66 (2011).

Rafuse, M. E. (1996). Working Capital Management: An Urgent Need to Refocus. Journal of Management Decision, 34(2), 59-63

Raheman, A. \& Nasr, M. (2007). Working capital management and profitability - Case of Pakistani firms. International Review of Business Research Papers, 3(1), 279-300.

Shin, H. H., \& Soenen, L. (1998). Efficiency of working capital management and corporate profitability. Financial Practice and Education, 8(2), 37-45.

Smith, K. (1980), "Profitability versus liquidity tradeoffs in working capital management", in Smith, K.V. (ED.), Reading on the management of working capital, West Publishing Company, St Paul, MN, pp.549-62

Van Horne James C. (2000). Wachowicz.Fundamental of Financial Management. (10th Ed.). New Delhi: Prentice Hall lnc. 